\author{
고온전단분쇄기술을 이용한 재샘/신재 EPDM 고무 \\ 블렌드물의 특섬 \\ 박현호* ${ }^{*}$ 이창섭 ${ }^{\dagger}$. 나섬택 \\ 화승 R\&A 신궁정헉신팀 \\ ${ }^{\top}$ 계명대학교 자연대 화학과 \\ 풀리원 기술연구소 \\ (2005. 4, 18 집수)
}

\title{
The Characteristics of Recycled/Virgin EPDM Rubber Blends by High Temperature Shear-crushing Technique
}

\author{
Hyun-Ho Park* , Chang-Seop Lee, and Seong-Toek Na \\ Hwaseung R \& A, Ltd, Kytmgnam 626-210 Korea \\ 'Department of Chemistr; Keimung Lhwersin; Daegu 704-701, Korea \\ ${ }^{\star}$ Polrone R\&D Center; Kymggi, Korea \\ (Received April 18. 2005)
}

\begin{abstract}
요 약. 신재 $\mathrm{EPDM}$ 고부와 계 $\mathrm{EPDM}$ 고두를 고온 전단분쇄기술로 분말화한 재료를 다양한 혼합비로 블 렌드불을 제조하고 재생재료의 함량에 따른 블렌드꿀의 가황 특성, 불리적 성질외 변화를 조사하였으며, 이 블 렌드물의 대열성. 대부동액성 및 압축영구줄음율을 측정하였다. EPDM 고무 신채에 고온 전단분쇄기술로 제 조한 재생 LPDM 재료를 $0 ~ 50$ phr까지 볼렌드하여 각종 물성을 측정한 결과. 재생 LPDM 고무의 배합조성이 $25 ~ 35 \mathrm{phr}$ 인 볼렌드물이 저가이면서도 분산성, 내열성. 내부동액성 시헌에 대한 물성변화율이 가장 각은 배합 구성으로. 나타났다.
\end{abstract}

주제어: EPDM. 고온전단분쇄기술, LPDM, Shear Crushing Technique

\begin{abstract}
Virgin EPDM and recycled EPDM fine particles that is crushed by high temperature shear-crushing technique from recycled EPDM were blended with the various mixing ratio to rubber blends. The cure characteristics and physical properties of these blended rubber compounding were investigated with the contents of recycled EPDM and physical properties of these blends for heat and antifreeze and compression set were also measured. Recycled EPDM materials prepared by high temperature shear-crushing technique were blended to virgin EPDM with the range of $0 \sim 50$ phr. The testing results of physical properties indicated that the rubber blends of recycled EPDM with $25-35$ phr turned out to be the best compounding showing good dispersibility, heat resistance and anti-freezer resistance and inexpensive in price.
\end{abstract}

Keywords: $\quad$ EPDM. 고온전단분쇄기술, EPDM. Shear Crushing Technique

\section{서 론}

산업의 발전파 더불어 코분자 물질은 후리 주위에 처 가장 많이 사옹되는 화학재료 중 하나가 되었다.
그러나 고분자물질을 생산하여 사용한 후 발생되는 폐기불은 또 다른 환경오염 문제를 발생시키므로 고 분자불질의 폐기불 처리는 고분자 신소재를 개발하 는 것만쿰 중요한 기술로 인식되고 있다. 
엘라스토머, 합성섬유. 천연중합체 능을 포합하는 고분자물질의 성질은 화학적, 물리적 구조 및 성질에 외존하며, 이들의 화학적 성질은 세라믹이나 급속의 성질들과 매우 다르다. 그리고 고분자물질의 불리적 성질은 기본적으로 비슷하나, 시간, 온도, 그리고 주 변 환경의 영향으로 모양과 구조는 변화될 수 있다.' 최근 욱리 챙활주변에서 각종 1 회 횽품을 비롯하여 고분자 재료의 사용량이 겁격한 증가하여 많은 폐기 물이 발생되었으며. 이는 오늘날 환경오역의 주법 중 의 하나로 지복되고 있다. 마라서 고분자꿀질과 관련 된 제조회사는 생산과 폐기불처리 문제를 동시에 도 려해야하며, 특히 수출을 위한 품목에서도 환경문제 를 해결해야만 생산 활동이 가능하게 될 전맘이나. 현 재 세계 각국에서는 자동차의 $100 \%$ 재활용화(Total recycling system)를 독포로 재생기술을 연구 중이며. 그 중 고두재료에 관련되는 기술은 미세분말화, 표면 처리기술, 혼련기술 등이 중요기술로 푈요성이 힌식 되고 있다.

현재 대량 발챙하는 대부분의 고무 폐기물은 소각 을 통해 연에너지를 회수하는 방식으로 처리되고 있 다. 그 이외에 재활옹을 목적으로 진행된 다양한 연 구 중 가장 실옹화 기능성이 힜는 기술은 폐고두를 미세 분말화하여 내충격성 충전재로 직칩 할용하는 방법과. 분말화를 통해 증가된 반응 표면적에 열분해 법 또는 Microwave 조차 등으로 표면활성화를 하여 가교 결합을 분러시키는 연구가 친행되고 있으나. 균 일하고 재현성 있는 탈류효과를 기대하기 어려운 실 정이다. ${ }^{-1-4}$ 최근에는 재생고무를 전축소재름 비롯하여 다양한 용도로 개발하여 제품에 적용하고 있으나. 지 급까지 선진국에 비해 국내의 계 고부 재할옹 기술은 초보적인 수준에 불과하기 대문에 재생품의 지하된 성능으로 그 횽도가 제한되어 있으며 아직 경제성이 확보되지 못한 실정이다.

현재의 기술적 패러다임으로 볼 때, 고부재료의 재 활용을 위한 두 가지 주요 해심 공정은 미세분쇄기술 (Size Reduction)마 탈류.기술" (Devulcanization)이다. 미 세분쇄 기술은 덩어리 고부 혐태를 입자화하여 표면 적을 증가시켜 후속공정에서의 반응도를 향상시키는 기술이며, 탈류기술은 고무재료의 특성인 탄성과 복 원력을 부여하기 위한 기출로서 가교구조름 끊어 성 형 이전의 원료 고부 상태로 회북시키는 기술이다.

현 재까지 고부재활용에 주로 사용된 기술은 기계식
상온 파쇄기술(Ambient Process), 냄동 파쇄기술(Crogenic Process) 및 궁랭식 파쇄 기술(TXML-25 Process) 등 이 있다." 최근에 개발된 고부재활용기술로서 고온전 단분쇄기술은 열경화성 고무 폐기불을 고온, 고압 환 경에서 특수 전단력으로 피분쇄불 네의 네부에니지 축적을 국대화시켜 임계접 도달과 함께 폭발적인 에 너지 분산을 통해 미레분말화 하는 방식으로서, 고무 재료의 미세분쇄 및 표면활성에 의하여 효율적인 표 면탈류가 동시에 구현되어 신재고부와 기의 동등한 수준의 불정을 가진 분말 상태의 재생재료를 제조할 수 있으며. 이는 원료고부로의 재적용이 기능하여 수 입대체 효과를 기대할 수 있는 환경친화적인 분쇄 기 술이나.

본 연구에서는 신채 EPDM 고무채료와 고온전단분 쇄기술을 이용한 재생 EPDM 분말고부를 일징비울로 블렌드하여 표면분산도, 불성 중 내열성, 내부동액성 및 압축영구줄음울을 확인하여 재생 분말 및 신재 EPDM 고무의 블렌드성을 조사하였다.

\section{실 험}

\section{시약 및 재료}

본 연구에 서 사용된 원재료 고부는 신재 EPDM 고 무(EPT4035, MITSUI, 일본)와 재생 분달 EPDM 고 무(E-200) 폴리원, 한국)를 사용하였다. 보강제로는 Fast extruder fumace(FEF) 능급의 국내 Korea Carbon 제폼을 사횽하였다. 그 밖에 첨가제로는 가소게인 P-90 오일(세)창석유, 한국), 가항촉진조제인 Zinc oxide( $\mathrm{ZnO}$. 한일아연, 한국), Stearic acid(S/A, LG 한국), 촉진제 인 M, TS(동양화하. 한국)와 가황제인 황(S. 미원상사, 한국)을 사용하였나.

\section{배합방법 및 시편제조}

본 연구에 이횽된 모든 시편은 ASTM D3192에 의 해 1차 혼련으로 배합하였으며, 1차 혼련에서는 용량 $1.6 \mathrm{~L}$ 밀폐식 혼합기(봉신)를 이용하여 $44 \mathrm{RPM}$ 속도 로 초기은도 40, 최종은도 120-130를 유지하였다. 부 입순서는 신채고무 및 고온전단분쇄기 (Rotor disperser) 름 이횽하여 제조한 재생 분말고무. 카본블랙 그러고 햑품 순으로 부입하여 5 분 동안 배합하였다. 배합불 은 혼련 후 고부 탄성구조의 열적안징성을 고려하여 상온에서 이간 동안 충분히 방치하였으며, 촉진제는 
Table l. The recipe for Virgin EIDM / Recycled EPDM rubber blends

\begin{tabular}{|c|c|c|c|c|c|c|}
\hline 재코명 & T-I & $T-2$ & $T-3$ & $T-4$ & $T-5$ & 비고 \\
\hline EPT3045 & 100 & 85 & 75 & 65 & 50 & \\
\hline 재생 분말 & - & 15 & 25 & 35 & 50 & \\
\hline FEF & 60 & 60 & 60 & 60 & 60 & \\
\hline P-90 & 30 & 30 & 30 & 30 & 30 & \\
\hline $\mathrm{ZnO}$ & 5 & 5 & 5 & 5 & 5 & \\
\hline$S i \Lambda$ & I & 1 & 1 & 1 & 1 & \\
\hline $\mathrm{M}$ & 0.5 & 0.5 & 0.5 & 0.5 & 0.5 & \\
\hline TS & 1.5 & 1.5 & 1.5 & 1.5 & 1.5 & \\
\hline $\mathrm{S}$ & 1.5 & 1.5 & 1.5 & 1.5 & 1.5 & \\
\hline Total & 199.5 & 199.5 & 199.5 & 199.5 & 199.5 & \\
\hline
\end{tabular}

two-roll millo에서 약 80 를 유지하며 10 분간 혼합하였 나. 각종 물성을 측정하기 위한 판상시편은 160 및 $120 \mathrm{Kg} / \mathrm{cm}^{2}$ 압력외 평판식 전열기를 이용하여 제조하 였다. 이 판상시편은 시편절단기를 차용하여 아령혐 3호의 시편 혐태로 제조하였다. 본 실험에서 적용한 고무재료 및 각종 첨가제의 배합비율을 Table 1에 나 타대었나.

\section{믈성촉정 및 특성분석}

재생 분말고무. EPDM Scrap을 고온전단 분쇄기로. 분쇄하여 제조한 재생 분말 EPDM 고부를 입자크기 분서기(particle size analyzer, PSA)를 이용하여 입자 크기 분포를 측정하였다.

가황 륵성. Virgin EPDM 고부와 재생 분말고무 블 렌드물의 가황특성을 조사하기 위하여 Moving Disk Rheometer(MDR P200, 알파테크놀로지, 미국)에서 가 항온도를 $160^{\circ} \mathrm{C}$ 로 설정하여 최대, 최소 토오 크( $\mathrm{Tmax}$ Tmin), 최적 가황시간인 Cure time(Te90), 최초 고부 경화시간인 스코치 타임(ts2)을 측정하였다. 또한 Mooney viscometer(Monsanto, 미국)를 이횽하여 121 에서 각 볼렌드물의 Mooney scorch time(T; 과 Mooney 검도 $\left(\mathrm{ML}_{1-4}\right)$ 를 측칭하였다.

믈리적 특성. 인장특성은 ASTM D-412에 마라 시 편을 제조하고 인장시험.기(Instron 10, 미국)를 사용하 여 $25^{\circ} \mathrm{C}$ 에서 $500 \mathrm{~mm} / \mathrm{min}$ 속도로. 측칭하였다. 열에 대한 영향을 조사하기 위해 인장시헙용 아렴형 시편 을 공기에 노출된 오븐에 서 각각 $100^{\circ} \mathrm{C} .120^{\circ} \mathrm{C} .150^{\circ} \mathrm{C}$. $180^{\circ} \mathrm{C}$ 로 유지하여 168 시간 동안 열노화시킨 후 인장 특성을 측정하였다. 또한 EPDM 고무는 라더에이터 호스에 주로 쓰이므로 부동액에서의 저항특성을 시
헙하기 위해서 물과 부동액 50.50 비율로 혼합하여 $115^{\circ} \mathrm{C}$ 에서 360 시간 동안 방치한 후 기계적 특성을 측 청하여 기본불성 대비 변화울을 측징하였다. 압축영 구줄음윻은 $120^{\circ} \mathrm{C}, 70$ 시간 시험조건에서 병기하였다. 압축영구출음울 실험에서 사용한 시험편은 원통형으 로 두께는 $12 \mathrm{~mm}$, 직경은 $29 \mathrm{~mm}$ 로 제조하였으며 압 축비율은 $25 \%$ 로 하였다. 볼렌드물의 표면분산도를 관 찰하기 위하여 인장실험이 꿑난 시편의 파단면을 SEM(HITACHI, 일본, $\$ 4200$ )을 사용하여 500 배 비울 로 확대하여 관찰하였다.

\section{결과 및 고찰}

\section{재생 분말고무}

고온전단분쇄기술은 고온 및 고압의 전단력을 이횽 해 분쇄불질 분자 내부의 에니지 축적을 극대화시켜 임쳬섬을 초과함과 동시에, 축적된 에니지의 폭발적 인 분산으로 미세하게 분쇄되면서 반응성이 큰 활성 상태의 미립자로 분말화하는 기술로서, 채생한 분말 고무는 기존의 분말이 가질 수 없는 화학적으로 활성 화된 표면특성을 가지고 있다. 이 기술에 서 사용하는 Rotor Disperser는 설비가 기존의 액체질소 분쇄기술 설비에 비하여 크기가 절반 이하이며, $850 \mu \mathrm{m}$ 이하의 분달고부를 시간당 $230 \mathrm{Kg}$ 칭도 생산할 수 있는 설비 이다. 본 신헙에서 측정한 채생 분말고무의 입도크기 분포는 Fig. 1에 나타내었나. 재생 결과 $500 \mu \mathrm{m}$ 이하 의 입도크기는 $90 \%$ 정도 얻을 수 있었나. 또한 이 기 술로 생성된 분말은 다궁성 궁극이 생성되며 꿀리적 및 화학적 촙착효과가 증대되어서 고부재료 표면외 반응성을 극대화시켜주는 장점이 있다. 


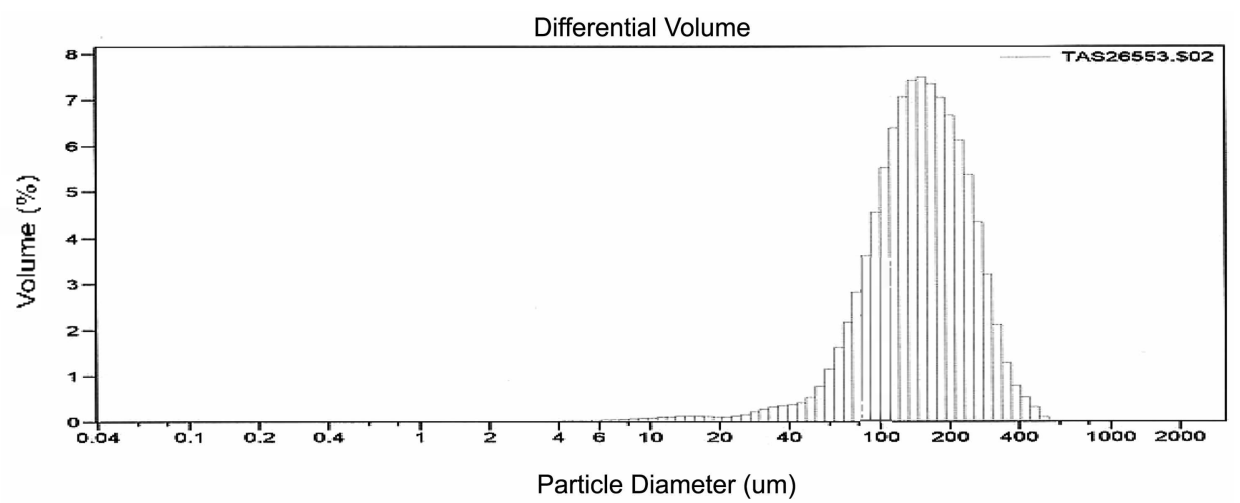

Fig. 1. Particle size distribution of the recycled rubber particles prepared by high temperature shear-clushing technique

Toble 2. Cure Characteristics of Virgin El'LM and Recycled EPDM mbber blends

\begin{tabular}{|c|c|c|c|c|c|c|c|}
\hline \multicolumn{2}{|c|}{ 항독 } & T-I & T-2 & $\mathrm{T}-3$ & $T-4$ & $T-5$ & 비고 \\
\hline \multirow{4}{*}{$\begin{array}{c}\text { M] }) \mathrm{R} \\
160{ }^{n} \mathrm{C} \\
* 20\end{array}$} & Tmax & 17.90 & 15.75 & 15.66 & 17.05 & 18.50 & \\
\hline & Tmin & 1.04 & 1.12 & 1.48 & 1.90 & 3.34 & \\
\hline & $\mathrm{Tc} 90$ & 8.31 & 9.34 & 10.52 & 9.72 & 9.49 & \\
\hline & $1: 2$ & 3.18 & 2.40 & 1.98 & 1.78 & 1.64 & \\
\hline \multicolumn{2}{|c|}{$\mathrm{MSIOO} 0^{\circ} \mathrm{C}$} & 19.4 & 18.9 & 22.4 & 25.6 & 39.3 & \\
\hline \multicolumn{2}{|c|}{$\mathrm{ML} 121^{\circ} \mathrm{C} \mathrm{Vm} / \mathrm{T}$} & $25.7 / 20$ & $25.2 / 14.32$ & 30.91503 & $25.2 / 14.33$ & $59.2 / 13.21$ & \\
\hline
\end{tabular}

\section{블렌드물의 가황 특성}

제조한 배합고금의 가황 득성을 레.으미테로. 조사 하었다. 일난적으로 탄성체의 가표결합은 둘 또는 그 이상의 사슬이 서로 접합뎐 결합을 말하는데. 가 교 견합된 중합체는 저어도 사술 당 둔 이상의 가교 견합을 포핚하며 다른 사슬자의 이차원적 또는 잠 차원 적 망상구조를 헝성하는 것으로 알려저 있다." 본 실험에서는 재생 분말 11 묻를 $0-50 \mathrm{phr}$ 빆위에서 0. 15. 25. 35. 50 phr 5 가시 비율로. 번화시켜 재생 분말고무를를 침가하었을 때 배합고묵의 가황툭성을 측정하였으벼. 이 때 나타난 측정값을 Table 2에 나 타내었다. 재생 분많고무의 함량이 쯩가할수록 scorch timo(Ts2)이 갑소하는 것은 본 수 있었다. Hamed 등 은 재생 분말고무의 배합 과징과 가황반응 중에 matrix

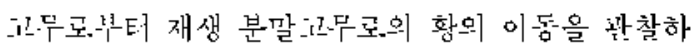
었으며. 이러한 황의 이동에 의해 새생 분말도목로 북터 가황촉진제 fragment의 matrix 고미-로의 화산 이 혹발딥을 보고하였나. ${ }^{22}$ 따라시 이러한 항의 분쇄 고부로의 이홍과 가항촌진제의 matrix 고부로의 이 동에 의해 반쇄고누 배합불의 scorch time은 간소하. 였다.

\section{물리적 특성}

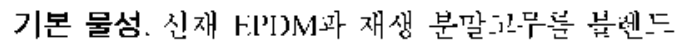

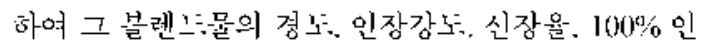
장응력를 측정하었나. 채생 분말고무- 블렌느의 합량 이 밚을수룩ㄱㄱ 인장강도 및 신잠율이 전자정으로 감소 하였으며 겅도는 상승하었다. Fig. 2는 재싱 분날고누 의 핚량 증가에 따라 족정한 인장강도의 견자를 나타 내었는데. 재생 분말-1ㅗㅡ무ㄷㅏㅏ 함유되면 신재 $100 \%$ 인 재 료에 비해서는 니코식 낮은 수줏으로. 나타났다. Fig. 3에서는 새료의 파난 시 콕정한 신장율 값을 나 타내었는데. 재생 분난고무가 천가되먼시 신장율은감소하:근 추세로 나타났다. 도한 $F$ ig. 4에는 시르를 $100 \%$ 신상변형 후은 나타난 인상응력 값은 나타내었으 며. 재생 분말표묻가 첨가되면서 인장응려이 즘가하 는 경항을 보였다. 이는 전체식으로. 보아 재생 분말 고믁가 분자사슬 내에 충전되면서 볼렌느로곰ㅁㅇㅢ 결 합길이를 짧게 해서 신장월이 떨어신 것으-로 생각된 나. 또한 인장강도에 비해 $100 \%$ 신잠변형 시 나타난 옴력 값의 상승폭이 큰 것은 재샘 반달고누끼리 안싱 적으로 재구성된 상호간 힌력 때눈인 것으로 판단뇌 며. 이는 입자의 감산배얼이 안징화 내시는 도정회되 


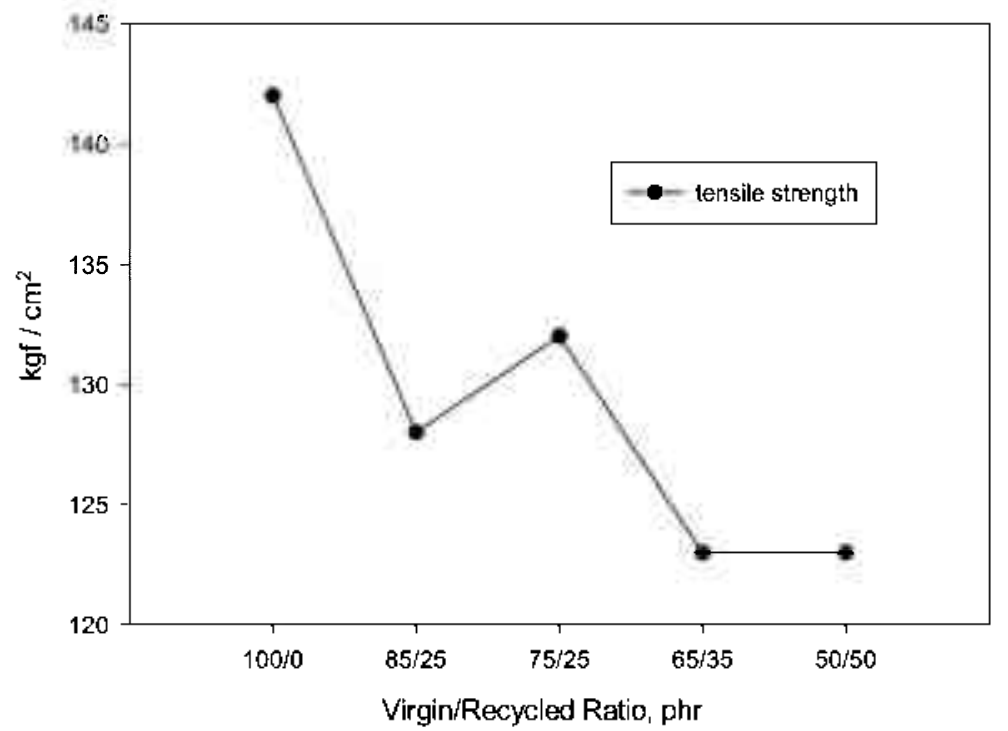

Fig. 2. Basic properties of tensile strength as a ratio of recycled EPDM.

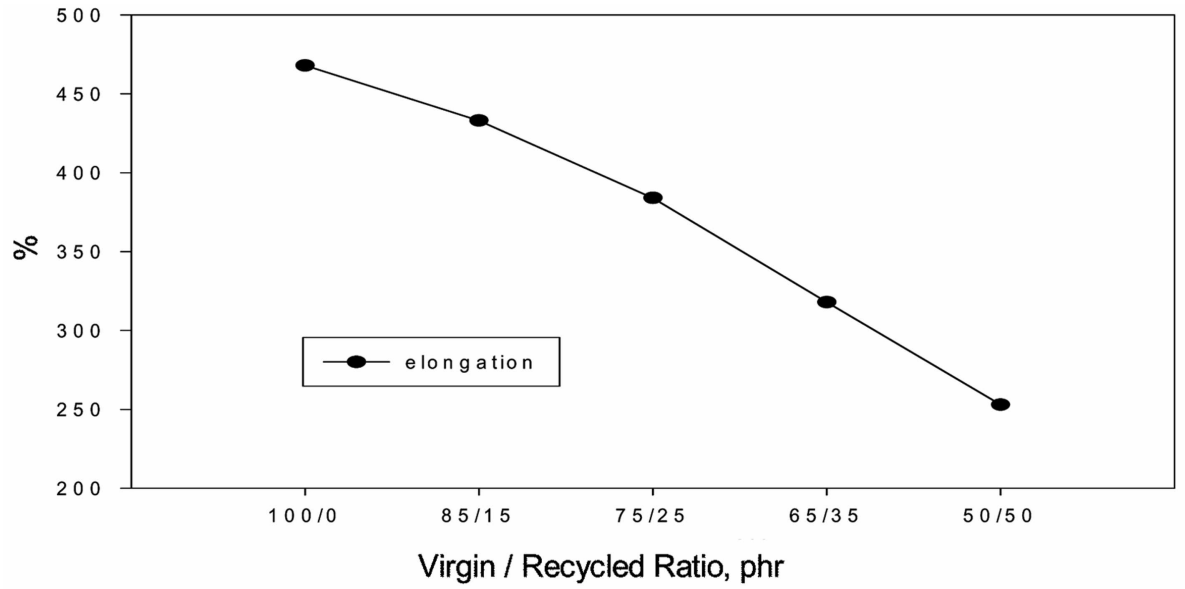

Fig. 3. Basic properties of elongation as a ratio of recycled EPDM

어 동적 성응-에 있어서 푈요한 특성이 발휘된다고 보. 고된 내욤과 일치한다. 1 1111

내열 륵성. 재생 분말 고무들ㄹ 첚가한 불렌드물의 네 열 특성을 촉정 하이 위하여 고목시편을 $100^{\circ} \mathrm{C} .130^{\circ} \mathrm{C}$. 150 'C 180 \% (에서 168시간 동안 3-화시킨 후 볼렌느 문의 경도. 인장강도. 신장율 능을 추정ㅇ하였으녀. 온 도별 인창강도 및 신장율의 변화윢은 Fig. 5 와 Fig. 6 에 삭각 나타내헜다. 재생 분말고누 핚댱에 마른 온 도널 인장깅도의 번화는 $130-150^{\circ} \mathrm{C}$ 은도에서는 재생 분말도맏가 많을수록 변회윻의 변화푹이 일정한.ᅡ.
180 "C 온도에서는: 다른 온도넘위와는: 다른 꿀성변화 를 보었다. 뜨한 $180^{\circ} \mathrm{C}$ 노화시힘에서는 재생 분말고 무의 함랑이 닪을수록 낮은 인장강도 넌회율을 보였 다. 채생 분말고묵가 전허 없는 신새 $100 \%$ 채료는 $180^{\circ} \mathrm{C}$ 온거에서 급격한 인장강너의 변화를 보었으나. 재챙 분막고무가 충진되면 불렏드문의 분자사술 연 속성이 낮은 상태로 되어 이 온도에서는 열을 가하디 라도 낮음 인상강도의 변화를 보였다. 반면에 Fig. 6 은 온도에 따든 북렌드불의 기본 불성 중 신장뮿에 대하어 네열 후 신장율의 번화율을 나다낸 깃으로.서. 


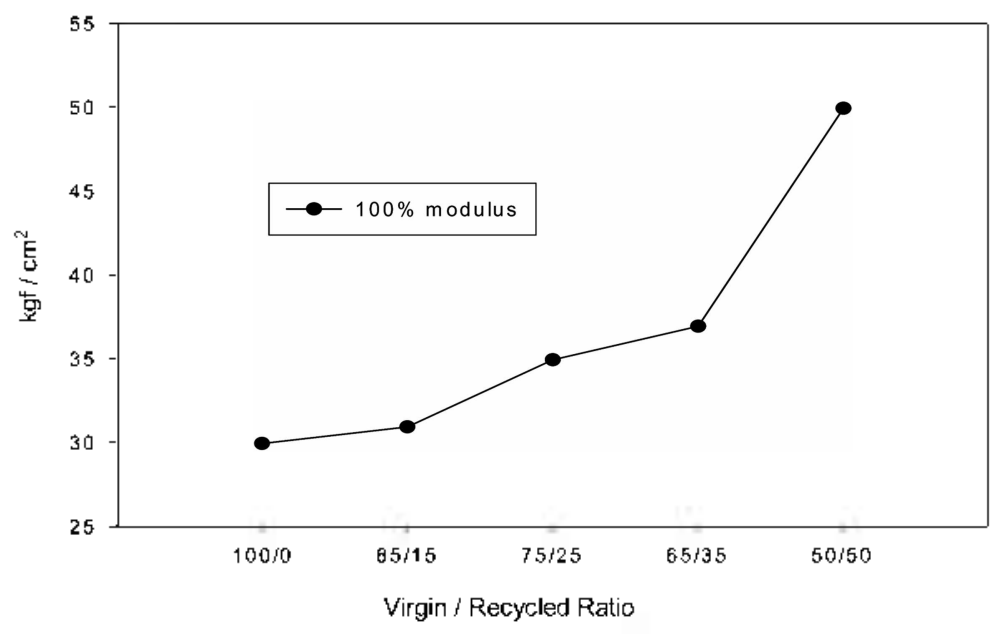

Fig. 4. Basic propertics of modulus as a ratio of recycled f.l']MM.

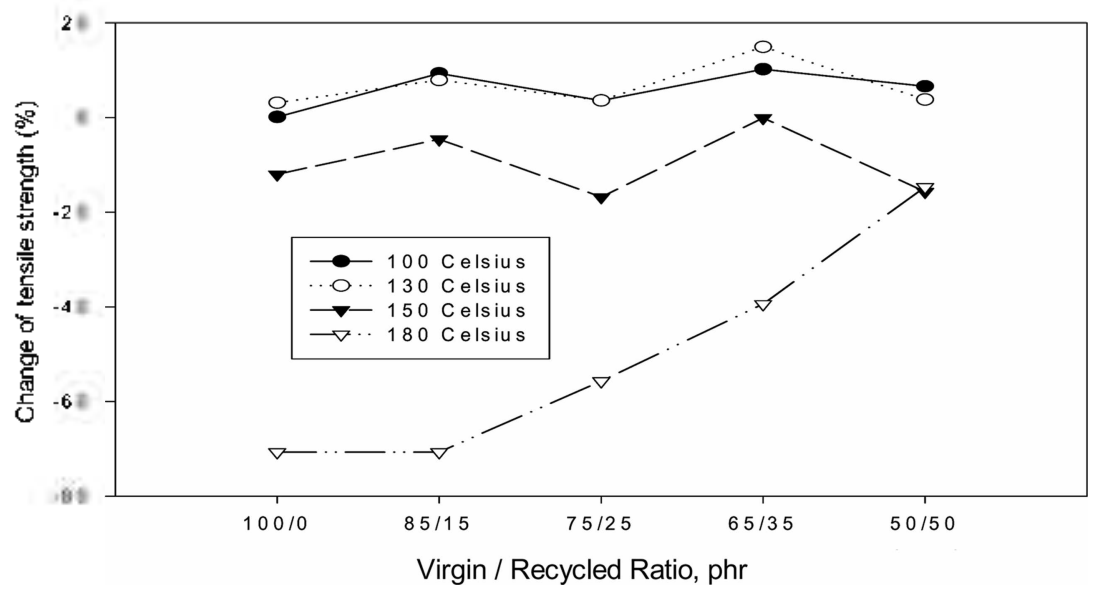

Fig. 5. Change of tensile strength measured alter heated aging test.

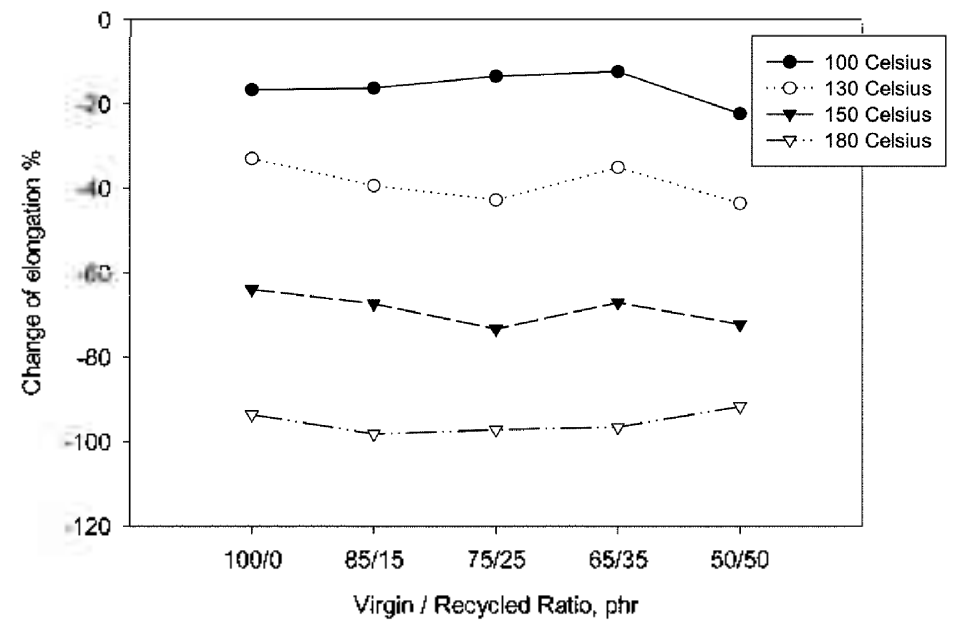

Fig. 6. Change of elongation measured after heated aging test. 
Fable 3. Anti freczing resistance of Vitgin FIPIOM and Recycled FIP] JM rubber blends

\begin{tabular}{|c|c|c|c|c|c|c|c|}
\hline \multicolumn{2}{|c|}{ 항보 } & {$[-1$} & T[-2 & $T-3$ & $T-4$ & $\mathrm{~T}-5$ & 비 고 \\
\hline \multirow{4}{*}{$\begin{array}{c}\text { 내부눋ㅇ애엉 } \\
*^{*} 115^{\circ} \mathrm{C} \\
* 360 \mathrm{IIR}\end{array}$} & $\mathrm{Hs}$ & +6 & +6 & -7 & -10 & +11 & \\
\hline & $\mathrm{Ts}$ & +15 & +16 & +16 & -20 & +25 & \\
\hline & $\mathrm{Eb}$ & -38 & -40 & -42 & -46 & -50 & \\
\hline & V & +3.5 & +3.9 & +4.0 & $\begin{array}{r}+5.5 \\
\end{array}$ & +6.0 & \\
\hline
\end{tabular}

Table 4. Compression set of Virgin EPLM and Recycled El'DM rubber blends

\begin{tabular}{|c|c|c|c|c|c|c|}
\hline 항 녹 & T-I & $T-2$ & $T-3$ & T-4 & $T-5$ & 비고 \\
\hline $120^{\circ} \mathrm{C} * 70 \mathrm{IIR}$ & $40.5 \%$ & $42.1 \%$ & 4505 & $50.5 \%$ & $52.7 \%$ & \\
\hline
\end{tabular}

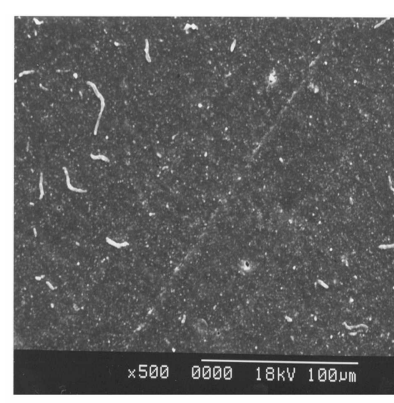

(a)

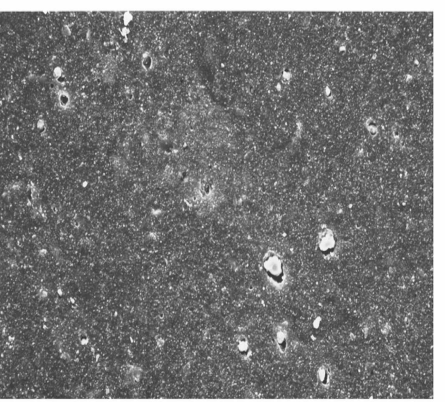

(d)

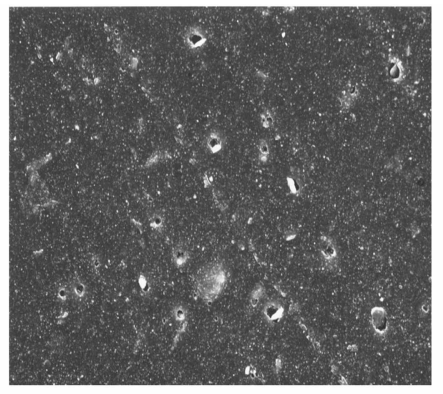

(b)

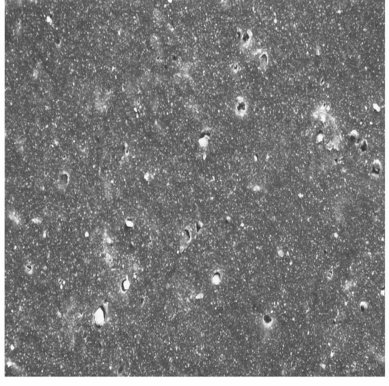

(c)

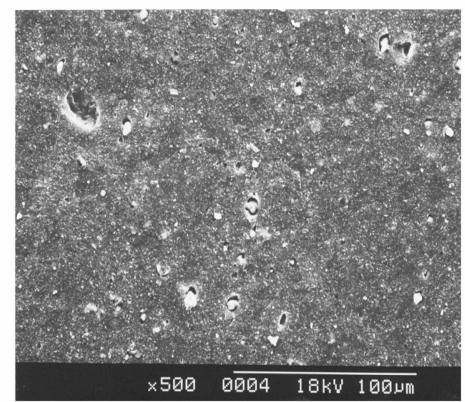

(e)

Fig. 7. SEM photographs of rubber surface obtained after breaking specimen. (a) Virgin Г.PDM 100 phr, (b) Virgin E.PDM 85 phr+Recycled Г:PDM 15 phr. (c) Virgin Г:PDM 75 phr-Recycled FPDM 25 phr. (d) Virgin Г:PDM 65 phr+Recycled F.PDM 35 phr, (e) Virgin E.PDM 50 phr+Recyeled E:PDM 50 phr.

온도가 $100^{\circ} \mathrm{C}$ 에시 $180^{\circ} \mathrm{C}$ 로 높아지년시 기논물성의 신상윢과 비교하혀 변화율이 증가하였다. 또한 삭 온 도조건에서 재생 반말고누의 핚냥이 증가핚에 따라 신장윻의 넌화는 일징하였는데. 이는 열에 의한 분자 사놀 절단은 제생 분말고무의 한량과 무퐌하나는 것 을 가레킨나.

내부동액성. 자봉차용 고무재로로 사용되는 LPDM 고무는 에털렌 헐레곤이 함유된 부농액에시 가장 난 이 사욤뇌고 있으므로 본 연구에서 사욤한 재료도 부 동액에 대한 저항성을 시험하였다. 시험방빕은 규징 뇐 은도와 시간 동안에 시편을 유체에 노출시키는 깃
이버. 시현의 노홀 전후 기게적 물짐 및 부커의 변화 율을 츤심하여 유체에 데한 재료의 지항싱도를 평가 하였다. 본 실힘에서는 사종차 부폼 충 라디에이터 호 스 규격을 근거로. 하어 $115^{\circ} \mathrm{C} .360$ 시간 동안 시료는

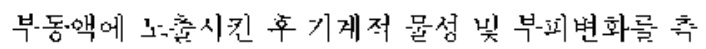
정하여 늘 전 문성과 비표하였으며 그 결과를 lable 3 에 나타내었다. Table 3의 문성을 보년 재생 꾼난고무 $25 \mathrm{phr}$ 분렌드문 까지는 니분랜드문인 T-과가 비교하 여 물성년화폭이 거의 동등한 수쭌이기나 : 도 이상으 로. 재생 분말곰ㅁㅁㄱㅏ 불댄드 되면 시료의 불성에 차이 가 있다. 이는 $25 \mathrm{phr}$ 까시는 재생 분말-1고두가 일바 탈

2005. Fol ts. ito 4 
황이 되어 분자사슬의 결합을 방해하지 않으나, 재생 분말고무의 합유량이 높아질수록 분자사출의 결합을 방해하여 분자구조가 느슨해지며 이로 인해 부동액 외 침투성이 증가하여 불성의 변화폭이 증가한 것으 로 판단된다.

압축영구줄음율. 동적인 압축이나 전단럭을 주는 부 분에 이용되는 가황고무의 가열압축에 의한 잔류변 혐을 측정하기 위해 압축영구줄음율 시험을 하였으 며 그 결과를 Table 4에 나타내었다. 이 시헙결과도 네부롱액성 시험결과와 같이 T-4부터 급격한 물성변 화를 보였으며, 이 또한 재생 분말고부가 분자결합을 방해하여 분자사슬 길이가 빫아짐으로 인해 가열압 축 후 복원력이 낮아친 것으로 사료된다.

표면분산상태 측정. 재생 분말 $\mathrm{EPDM}$ 고무를 0,15 . $25,35,50 \mathrm{phr}$ 비율로 신재 EPDM 고무에 블렌드하 여 시편을 제작하고 전자현미경을 이용하여 표면분산 도를 측징하였으며 그 결퐈를 Fig. 게 나타내었다. 재 생 분말고부가 첨가되면서 분산성이 떨어지는 것으 로 퐌단되며 재생 분말고무 $25-35 \mathrm{phr}$ 까지는 미분산 약줌이 보이지반 $50 \mathrm{phr}$ 이 포함된 시편과 비교하여 양호한 분산상태를 보이고 있다.

\section{결 론}

고온전단분쇄.기술로. 제조한 EPDM 재생 분말고무 를 신재 $\mathrm{EPDM}$ 채료와 블렌드 하여 기본물섬 및 내 열성을 측정하였으며 실헙결과를 바탕으로 다음과 같 은 결론을 얻었다.

1. 재생 분말고무는 분자차슬네의 항 결합을 일부 절단하여 적정가황 시간이 길어.지며. 또한 재생 분말 고무 내에 잔쫀하는 촉신제가 볼렌드물에 영향을 주 어 스코치 시간이 짧아지는 것으로 판단된다.

2. 재생 분말고무가 가황 시 분자결합을 방해하므로 인장강도가 저하되며 그로 인해 신장율이 저하되나. 재생 분말고무 끼리의 결합력으로 인해 모률러스는
향상된다고 사료된다.

3. 외부 열에 의한 볼랜드물의 분자사술 절단은 재 생 분달고부 함량과 부관하며 재생 분말고부가 네열 후 불성에 미치는 영향은 없는 것으로. 나타낯다.

4. 재생 분달고무가 첨가되면서 분산성이 떨어지는 것으로 판단되며, 재생 분달고부 25-35 phr까지는 미 분산 야폼이 보이지만 $50 \mathrm{phr}$ 과 비교하여 양호한 분 산상태를 나타내었다.

5. 본 연구에서 신채 EPDM 고무에 대한 최젹의 재 생 분말 EPDM 고부의 비윻은 25-35 phr로. 나타낮다.

\section{인 용 문 헌}

1.J. Il. Choi, "폐 폴라스턱과 환경”, 푸른길, Chaㄹ. I, 2000: 35 .

2. B. D. Baumant. "High-łalue engineering materials from scrap rubber", Rubber Horfl. May, 30 (1995).

3. J. [D. Osborm. "Reclaimed tire rubber in TPE compounds". Rubber Horld. May, 34 (1995).

4. M. W. Rouse, "Development and application of supperfite tire powders for compounding". Rubber World. June, 25 (1992).

5. R. Kohler and J. O' Neill, Oct. 17-20, 1995. Cleveland, Abstract in Rubber Chem. Teclmol. 1996. 6\%. 146.

6. I. Scheirs, "Polymer Recycling". Chap. 12, John Wiley \& Sons Ltd., Chichester, 1998.

7. I. Franta. "Elastomers and Rubber Compounding Materials": Chap. 5. Elsevier, 1989.

8. KS m 6518 , 가황고무 불리시험방법.

9.J. Y. Jin, H. S. Kiml. and S. Y. Choi. "합성고무 보 강제 Silica의 화학처리에 관 한 연구(1)-Silica의 MDI 처러", I. kor Ihs. of Rubb. Ind, 1995, 30x 1) 45.

10. A. Casale. R. S. Porter and I. F. Johnson, Rubber Chemistry athd Technolog; 1971. 4t. 534.

11. M. W. Ranney, K. J. Sollman and R. J. Pickenell, Rutber Chemistry and Technolog: 1972, 45, 1166.

12. D. Gibala and G. R. I tamed, Rubber Chem. Techol., $1994,67,636$ 